Article

\title{
The relationships between social pedagogy, social work and child protection: the case of Estonia
}

\author{
Mare Leino ${ }^{1,2}$ \\ ${ }^{1}$ Associate Professor of Social Pedagogy, Tallinn University, Narva Road 25, Tallinn, Estonia; eram@tlu.ee or \\ mareleino@hotmail.com \\ ${ }^{2}$ Head of the Master's Programme in Social Pedagogy and Child Protection, Tallinn University, Tallinn, Estonia
}

How to Cite: Leino, M. (2021). The relationships between social pedagogy, social work and child protection: the case of Estonia. International Journal of Social Pedagogy, 10(1): 11.

DOI: https://doi.org/10.14324/111.444.ijsp.2021.v10.x.011.

Submission date: 2 November 2020; Acceptance date: 31 August 2021; Publication date: 28 September 2021

\section{Peer review:}

This article has been peer-reviewed through the journal's standard double-blind peer review, where both the reviewers and authors are anonymised during review.

\section{Copyright:}

(C) 2021, Mare Leino. This is an open-access article distributed under the terms of the Creative Commons Attribution Licence (CC BY) 4.0 https://creativecommons.org/licenses/by/4.0/, which permits unrestricted use, distribution and reproduction in any medium, provided the original author and source are credited • DOI: https://doi.org/10.14324/111.444.ijsp.2021.v10.x.011.

\section{Open access:}

International Journal of Social Pedagogy is a peer-reviewed open-access journal.

\begin{abstract}
This article analyses the context of social work and social pedagogy in Estonia. It also introduces the differences, commonalities and overlap of the two concepts and their teaching. Courses in both disciplines are taught at Tallinn University in the School of Governance, Law and Society. At Tallinn University social work has been taught at three levels (BA, MA and PhD) since 1991; the Master's in Social Pedagogy and Child Protection started in 2002. As the term 'social' encompasses several meanings, it also influences the practice in the social field - an overlap here can be considered to be a positive aspect, because the aim of both social work and social pedagogy is a better life. In Estonia social pedagogy is connected with social work through child protection. This article first presents a short overview of the situation in Estonia. It then introduces the main principles and theoretical backgrounds of the concepts and the education of social work and social pedagogy.
\end{abstract}


Keywords social pedagogy; child protection; social work; higher education; curriculums

\section{The emergence of social sciences in a post-Soviet country}

As social work and social pedagogy are partly connected (at least through social problems), it is important to share general facts as well as background information about the social situation in the country. Estonia is the northernmost of the Baltic States, which lies on the east coast of the Baltic Sea, with Latvia to the south and Russia to the east. The territory of Estonia covers 45,227 $\mathrm{km}^{2}$. After the Second World War, Estonia was incorporated into the Soviet Union and regained its independence in 1991, and during the same year, endorsed the United Nations Convention on the Rights of the Child. The Estonians are Finno-Ugric people; the official language is Estonian. Its population of 1.3 million makes Estonia one of the least populous member states of the European Union. Of the population there 69.7 per cent are Estonians, 25.2 per cent Russians and a small proportion is comprised of other nationalities. Estonia belongs to the North Atlantic Treaty Organization and has been a member of the EU since 2004. Since regaining independence, the political environment has been stable and enabled implementation of various economic and social sector reforms, which aim to further ensure stability of health care services. The economic crisis has seriously affected the living standard of families with children; most of them have not experienced any increase in wealth since 2007. In 2011, 17 per cent of all children under 8 years of age lived in relative poverty, 9.5 per cent in absolute (extreme) poverty, and 9 per cent in severe material deprivation (Julge, 2016, p. 63). According to the Statistics of Estonia (2019), 21.7 per cent of the Estonian population lived at risk of poverty and 2.4 per cent lived in absolute poverty in 2018 . Social transfers - i.e. state benefits and pensions - helped to prevent people falling into poverty. Without including these in income, 39.1 per cent of the population would have been at risk of poverty and 22.7 per cent in absolute poverty (Statistics of Estonia, 2019).

According to the Baltic News Service (BNS Survey, 2019), the average Estonian household has six months' worth of savings set aside; one-third of Estonian households, meanwhile, would be able to maintain their current standard of living for just one month; while 6 per cent of Estonians reported they had no savings at all. Mrs Uusma, the head of life and health insurance product development at the insurance firm ERGO, said it appears, based on the results of the survey, that many Estonian households would find themselves in trouble if a member of the household were to fall ill or be involved in an accident. The survey findings also indicate that of Baltic residents, Estonians are the most inclined to see themselves as subject to material deprivation, with 34 per cent of respondents in Estonia reporting that they cannot cope financially - compared with 31 per cent in Latvia and 20 per cent in Lithuania (BNS Survey, 2019). This influences also social work and social pedagogy in the country, because the target group of both fields are people in need.

Rõõm and Villmann (2002) analysed the changes in the Estonian labour market since the early 1990s:

this period was characterised by extensive structural rearrangements related to the process of economic transition. Particularly in the early stages of transition, higher unemployment indicators are usually considered to be an inseparable part of the restructuring process, often even an indication of its scope. The increase of unemployment is the result of a reduction of production and is usually associated with cutbacks of workforce in state-owned companies. From less than 1 per cent in 1991 unemployment rose to 13.7 per cent in 2000. (p. 1)

Since the 1990s unemployment in Estonia has decreased: in September 2020 it was about 8 per cent but, due to the COVID-19 pandemic, the prognosis for 2021 and beyond is pessimistic. The statistics relating to social problems in the country gives a context, bridge or overlap to education and practice of social work, social pedagogy and child protection.

The short message of the current statistics is clear: social workers and social pedagogues are needed in Estonia. Even in the context of the social security system there are still people in need.

\section{Social work and social pedagogy in Estonia}

As both Master's courses (social pedagogy and social work) are taught at university level in Estonia, they are considered to be academic disciplines (the role of practice in those curriculums is marginal). 
According to Ewijk (2016), who has been a visiting professor in Estonia: 'a profession is academic when the discourse of it has been developed and lead from universities, like is the case of Estonia' (p. 38). Sünker and Braches-Chyrek (2009) add:
Social work contextualisation and place in the academic system is characterised by controversies; on the one hand in conceptions of social pedagogy in which social work does not play a role, such as youth education work and, on the other hand, in the conceptualisations that subsume the social pedagogical areas under the term social services. The question of social pedagogy's place in the academic system is linked to the theoretical interest in the structure of the relationship between individuals and society and the effect that education has on the roles of individual social stakeholders. (p. 24)

According to Kornbeck (2009, p. 217), in many countries, social pedagogy seems to be less dependent on fixed, canonised sets of acknowledged methods than is the case for social work. In Estonia the overlap between social work and social pedagogy is connected to social problems such as unemployment, poverty or financial insecurity. Serious problems are always seen in schools, because children suffer when something is wrong in the family. And the existence of different concepts (of social pedagogy and social work) is a sign of different content: the former deals with children and adolescents; the latter's target group are adults. In Estonia there are also different professional standards for social workers and for social pedagogues. This emphasises the difference: they are two separate professions/disciplines/fields. Furthermore, while social pedagogues mostly work in schools, social workers are employed by local governments. To name one fundamental difference between those two professions, social workers (and also child protectors) can share social benefits (money), but the tools of social pedagogues are only words and network information. And here the Estonian-specific aspect comes to the fore. At Tallinn University, the headline of the MA programme is Social Pedagogy and Child Protection - the diploma in this curriculum qualifies individuals to work in both fields: as social pedagogues and/or as child protection officers. The duality is practical, especially in a small country. About one-third of subjects in this curriculum are connected to child protection, one-third to social pedagogy and the remaining third are general themes (research methods, interdisciplinary project-work, psychology, law, IT). All subjects in this curriculum are obligatory for all students (the curriculums can be found at https://ois2.tlu.ee/tluois/kava/STSPM/21.YK\#). Only in the second year of the MA are course students divided: social pedagogues prepare their thesis in one group; and child protectors in another (also the professors are different). According to the law, child protectors in Estonia must have a Master's degree in social pedagogy and child protection, or in social work.

As previously mentioned, in Estonia most social pedagogues work at ordinary schools (sometimes also in kindergartens or in vocational schools); meanwhile child protection officers work for local governments. Social pedagogues are part of the support system in schools (along with psychologists and special educators) and their main duty is to help students and teachers to cope with academic tasks and/or social relations. Social pedagogues in Estonia are bridges between school, parents and support system within and outside school (Leino, 2002, p. 9).

Child protectors are government officers - they represent the state. At local government level they make decisions about the whole family (including those of a juridical nature). In smaller city governments one person sometimes fulfils the role of both child protector and social pedagogue. This has been one reason to create and continue with our dual curriculum.

Social workers in Estonia are mostly employed in local government - sometimes also in hospitals and care homes. After university, child protectors and most social workers are located in the same building (in different offices); but during the study, child protectors and social pedagogues are located in the same classroom (but separate from students of social work). It may sound uncommon, but so far this kind of model has been working well (Leino, 2010, p. 40). In curriculums there is an overlap in context of research methods, but theoretical subjects for social pedagogues, child protectors and social workers are different.

The course in Social Pedagogy and Child Protection has been popular from the very beginning there are about 4.5-5.5 candidates per study place every year. The Social Work course attracts about 1.3-1.6 applicants per study place. Both courses have an intake of 35 students. In addition, both courses are 'open' - meaning that a student can enter into the MA programmes if their BA degree is from a connected area; for example, (preschool) teachers, youth workers, lawyers and so on are welcome onto 
the MAs. (Most Master's programmes in Estonia are 'closed' - to enter into an MA programme the applicant's BA must from the same field.)

The significantly higher popularity of social pedagogy and child protection could be explained by the fact that in the labour market two professions are always better than one. Another pull factor is that the holiday entitlement for social pedagogues is long (56 days - the same as for teachers). The earning potential of social pedagogues is a bit better than of social workers (but both professionals earn in most cases a low average of $€ 900-€ 1,300$ per month) (see https://www.palgad.ee/salaryinfo). According to official statistics, the average gross salary in Estonia in 2020 was $€ 1,433$ (Statistics of Estonia, 2020).

It is also important to mention that higher education is free for locals in Estonia - so, to study something at university is popular among all age groups; and holding a degree or diploma helps to boost individuals' employability. According to law, services of the three professions of social work, child protection and social pedagogy must be guaranteed for citizens in every district; at present there are not yet sufficient numbers of personnel in those fields.

Social security departments in Estonia were created in the 1990s within local governments; there was a movement to take the organisation of social work and welfare from the Soviet-era centralisation to the grassroots level - back to the local authorities. Complexities of a transitional society offered real challenges for the social system, but there were no professional social workers. For these reasons, Tallinn University (in 1991) and the University of Tartu (in 1992) started to educate social workers (Tamm, 2010, p. 14). Since the turn of the twenty-first century it has also been possible to study social work in other schools, mostly at the level of Practical Higher Education (Self-Evaluation Report, 2020). The list of institutions with courses in social pedagogy and/or social work is presented in Appendix A (Erasmus students are welcome).

\section{Theoretical background}

Courses in social pedagogy/child protection as well as the social work programme at Tallinn University are influenced by experts from Finland, Germany, the Netherlands, the UK and the USA. The programme of social work was established right after Estonia regained independence, when the country lacked expertise in most fields (as the state turned from socialism to democracy). Luckily, foundations were created in the world for supporting post-Soviet countries; and as result many professors in the 1990s came from abroad: mostly from Finland (a distance of only about $80 \mathrm{~km}$ ), but also from other countries. For the programme of social work, the main author has been Professor Malcolm Payne, whose books have been used as the basic study materials, and who has also given lectures at Tallinn University (most recently in December 2019). For social pedagogy the main theoretical background comes from Germany, because the concept was created and developed there in the nineteenth century. Influences from Germany fit into Estonian culture for various historical reasons.

According to Kornbeck (2009), the 'social professions' may thus be seen as a broad conceptual sphere covering professional education, professional practice and related research, and a wide range of helping activities. Yet while it is true that the exact definition of the professional groups that make up the 'social professions' varies considerably from one country to another, as do the limitations and articulations between them, the presence of some type of social pedagogy is a reality in most European countries (Kornbeck, 2009, p. 211).

Both social work and social pedagogy are disputable concepts - partly because the word 'social' has several meanings and partly because of the specific cultural background of every country. According to Payne (2005):

People do not agree about what social work is, and different groups within social work argue for and against different views. Moreover, what they do every day as social workers, creates social work. We call it a social construction, because it does not exist as a reality, but as ideas, and what it is emerges from our debates and actions. (p. 7)

In reality social work and social pedagogy are connected through social problems. In a small country, social workers must have a broad profile. This is the reason why our students learn about law, psychology, case studies, special education, crisis management and research methods (qualitative methods are more popular among students, but quantitative are taught and used also). Here an overlap between curriculums can be considered, which is necessary, and the research methods are the same in both fields. 
One new subject - an interdisciplinary project - is compulsory for all students at Tallinn University, where those from different departments create a joint project together (taking one or two semesters to complete). As interdisciplinarity is the main idea, students from the social protection branch work together with others, and also social work can meet with social pedagogy (among other subjects). Through this process, social sciences gain overlaps with other disciplines.

As we have seen in recent years, problems and crises (be they financial, environmental, political or health-related) are getting more global, unpredictable, complex and even fatal. Wherever or however a problem starts, its consequences are social. This influences the role of social sciences in the society. According to Webb (2006):

we must think of social work as occupying a specifiable ethical location in social space that belongs to a traditional order underpinned by strong evaluators and social solidarity. It is at the same time expensive in having acquired ethical identities and political skills to counter the hegemony of neo-liberalism. If you want to stick a label on this project, call it 'neo-humanism' - in acknowledgement of the longstanding European tradition of humanism with its various considerations of shared moral understanding, the cultivation of self, mutual reciprocity, social virtues and the common good. (p. 233)

Now, in the context of the COVID-19 pandemic, solidarity and neo-humanism are actual concepts in social sciences (also at the curriculum level). Because of fast changes all over the world (creating new problems in many areas), the curricula and teaching at universities must sometimes be updated even during the course of a single school year. Both social workers and social pedagogues need some joint competencies to cope with real life. Despite being two different curricula, the target group and problems are partly similar. In 2019 Professor Payne, during his lecture at Tallinn University, presented his newest book (Payne and Askeland, 2019), in which he wrote:

social work and social pedagogy on the European continent have been brought nearer to each other, and currently many educational institutions ward a joint degree. Historically social work training in these countries was based on social sciences, took place in separate schools, and prepared students for public welfare services with poor relief, social movements and voluntary work. Social pedagogy was taught youth outside the school system to cope with life, and by means of therapy establish harmonious relations between individuals and society. Pedagogy has a different connotation in the UK, having been a technical word for teaching skills. However, in recent years, European social pedagogy has been explored as a way of reforming childcare practice. (p. 84)

As long as a concept is not permanently fixed, it is alive.

According to Petrie (2011), the term social pedagogy relates to three distinct but connected fields: social policy, professional practice and theory. Social sciences relate to those three fields. The adjective 'social' is significant for all three (Petrie, 2011, pp. 75-7). According to Payne (2005) pedagogy is a 'reflexive' practice, in which all participants are seen as affecting each other and as affecting those processes in which they are jointly involved (see also Petrie, 2011, pp. 75-7). The joint concept could be called social protection - which is the name employed at Tallinn University. There are covering concepts or bridges in many countries between social work and social pedagogy: in Estonia social protection; in Belgium and the Netherlands it is orthopedagogy (Broekaert, Van Hove, D'Oosterlinck and Bayliss, 2004 , p. 206), which is defined as return to correctness through use of educational theories and more specifically as a science of action aimed at children and adults experiencing difficulties in educational situations. A joint concept in Germany is Soziale Arbeit (= Sozialpädagogik + Sozialarbeit) (Schilling, 1997, p. 337), where both disciplines are considered as part of social politics. In English it could be called social approach (or social work in its broader meaning), where social constitutes everything what happens between people. The problem (or richness) at play is that 'social' itself has many meanings. According to Eriksson and Winman (2010):

if social is understood as something common (also including culture), and pedagogy as learning, this means that social pedagogy is about together supporting people in their development towards becoming independent participants in a democratic society. Social pedagogy is a tool for understanding societal changes in the evaluation of individuals in order to offer them the opportunities/education needed to change their current situation. (pp. 8-9) 
I agree with this point of view. Social pedagogy helps to cope in society and should be something more general than it is now (in Estonia this concept is mainly focused on general education). The message of Eichsteller and Holthoff (2011) should be stressed: 'within the social pedagogic tradition education has two aspects, person-centred and socio-political: it provides opportunities for personal development towards independence, but also has a socialising function in reinforcing social solidarity and interdependence' (p. 33).

According to Gustavsson (2010, pp. 19-20), the aim of social pedagogy is to make human life better. But a good life cannot be realised individually: a good life for oneself is a prerequisite for a good life for others too. Finnish experts Nivala and Ryynäinen (2019) add: 'there are connections between social pedagogy and philosophy, sociology, social psychology, andragogy, social sciences, youth work, empowerment, social work, pre-school education, special education, teachers' education and educational sciences in general' (p. 13).

Here seems to be a good point to introduce the key term animation socioculturelle - a famous concept from the Southern European tradition of social pedagogy. It could partly translate as empowerment, but that does not represent a 100 per cent accurate translation. The words anima or animus in Latin mean giving life, or to start moving. This concept came to Estonia from Finland, where Professor Leena Kurki from the University of Tampere has focused on this term. Her main message is that a social pedagogue must show clients the best possible way to reach a better future. Re-anima is activating: for solving problems one must do something differently (Hämäläinen and Kurki, 1997).

For students at Tallinn University animation socioculturelle has been a favourite concept, because it helps to activate young people to find the best possible way out of difficult situations (Leino, 2012, pp. 56-62). Many Finno-Ugric Estonians are introverted (Mawhood, 2015), and part of their nature is the tendency to be depressive (Opikova, 2019). For example, there are many negative old wisdoms/sayings in Estonian culture, such as: 'don't laugh before the evening'; 'who laughs last, has better laugh'; 'sorrow comes after great joy', and so on. This being the case, the average Estonian may have need of animation socioculturelle, even without serious social problems. In Finland, the prevention of social problems is a priority. This is the approach we'd like to develop in Estonia too because prevention is cheaper and more effective than cure. But so far, focusing on prevention has been a luxury only for richer countries. In post-Soviet countries it is hard enough to try to solve the consequences of social problems - therefore most resources go towards this activity.

The role of prevention and/or early intervention cannot be underestimated, especially among younger generations. According to Tierney and Baumeister (2021):

You are most affected by the negativity effect during your younger years, when you most need to learn from failures and criticism. Older peoples' lives may not seem better by objective standards, but they feel better and can make sounder decisions because they can afford to ignore unpleasant learning opportunities and focus on what brings joy. (p. 2)

As the only tool of social pedagogues is communication, and as the whole of social science is about reflection, animation socioculturelle is a precondition of progress. Its Latin root may sound complicated, but actually it can simply be a kind word or fresh look at something. Barreiro and Endsleff (2020) stress the role of social representations, where - in my opinion, at least - animation socioculturelle starts:

Individuals live in a symbolical order that is taken for granted because they were born in it. They consider it as the natural world that is only questioned when something unexpected happens and a new meaning-making process is necessary to re-establish the balance with the environment. (p. 75)

Social representations are signifying structures that provide a shared code of what individuals from a social group consider to be real. Individuals construct social representations in their communicative exchanges and daily interactions to facing everyday life issues. (p. 73)

A social pedagogue, with the help of re-anima, gives a new start and helps an individual to find a new way or simply to gain a new perspective. 


\section{Conclusion}

According to the results of the survey of Baltic residents, Estonians are the most inclined to see themselves as subject to material deprivation, with 34 per cent of respondents in Estonia reporting that they cannot cope financially - compared with 31 per cent in Latvia and 20 per cent in Lithuania (BNS Survey, 2019). This influences social work and social pedagogy in the country because the target group of both fields are people in need. In summary, social pedagogy and social work in Estonia are rather corrective activities. Based on this paradigm also courses in social pedagogy and child protection and social work have been developed. In a post-Soviet country this is clearly significant progress - during the Soviet era social problems were not talked about - nowadays we have a quite well-functioning social system. According to Sünker and Braches-Chyrek (2009):

the basic figure of social pedagogical thought, which occurs clearly throughout the course of history, is defined by the assumption that the relationship between individuals and society is conflictive and that social conditions are determined by the suppression of individual. The goal of social pedagogy is, firstly, to improve the unequal social conditions by socio-political means, and second: to enable individuals to fight their own battle to improve social conditions. Hence, the concept of social pedagogy focuses on the social dimension of education in an exciting way. (p. 24)

Social pedagogy is part of a support system. The role of social support is to help people to cope in society. Böhnish and Schröer (2011) stress:

The social pedagogical concept of 'coping with life' presents itself as a two-circle model, consisting of an inner circle of psychodynamically motivated and socially directed personal coping behaviour and an outer circle of socio-structural contextualization of society's 'coping demands', social room to manoeuvre, opportunities and possibilities in tension with societal parameters. The inner circle can be described as the magnetic field of psychosocial striving for agency in life-constellations with ever-blurring boundaries. Here three 'coping stimuli' converge: the need for stable self-worth, for corresponding social recognition, and for the experience of self-efficacy (the feeling that one can achieve something and control one's own actions). This inner magnetic field is polarized towards biographical agency, which seeks unconditional realization, even if this cannot be found in the given social context. Social recognition can be sought in different ways: both in the cultural context of prevailing social norms and in conspicuous, attention-grabbing behaviour. (p. 16)

In Estonia, in the context of social pedagogy and child protection we stress the importance of dialogue: people with problems are the best experts in themselves. We teach students, for example, how to involve involuntary clients, how to hear the voice of somebody in the middle of crisis or how to find acceptable compromises. According to Schulte (2013), the social expert/practitioner should help to reflect and/or give feedback, especially on hidden sides of problems; this being the case, the best social practitioner is some kind of professional coach (p. 196). Keupp (2002) stresses the important role of research, which he calls an identity development (p. 314). The MA programme at Tallinn University ends with a thesis, which is obligatory (the Master's exam is not an option). The ability to research is useful in everyday work as an analysis tool. To see a broader perspective, and a human being in a holistic way, 'coping stimuli' are needed at first for experts, who can then share them with clients. According to Kornbeck (2009, p. 223), social education may be defined as the theory about how psychological, social and material conditions and various value orientations encourage or prevent the general development and growth, life quality and welfare of the individual or the group. It fits well with the Estonian teaching paradigm, and also with Sünker and Braches-Chyrek's (2009) statement: 'The question of social pedagogy's place in the academic system is linked to the theoretical interest in the structure of the relationship between individuals and society and the effect that education has on the roles of individual social stakeholders' (p. 24).

\section{Declarations and conflicts of interest}

The author declares no conflicts of interest with this work. 


\section{Appendix A: courses in social pedagogy and social work in Estonia}

\section{- Social Pedagogy courses in Estonia}

\section{Bachelor's:}

(1) Tallinn University has a BA study programme, Social Pedagogy, in the Faculty of Educational Sciences.

(2) Tartu University has a BA study programme, Teaching Humanities and Social Subjects in Basic School, where social pedagogy is one option (among others) for specialisation.

\section{Master's:}

Tallinn University's School of Society and Law (branch of social protection) offers Social Pedagogy and Child Protection. This is the only MA programme in Estonia covering social pedagogy and also child protection. The common core of social pedagogy and children's care is a child in need. To evaluate the need of assistance, a child should get the expertise of both specialists. Based on the available statistics, the number of children identified as being in need of assistance has increased in recent years. In 2007, 2,396 children were registered ( 0.9 per cent of the total population of children in that year), whereas in 2015, the number of children registered had risen to 1.3 per cent of the total population of children (Statistics of Estonia, 2019).

The importance of social pedagogy is growing; professional specialists are in demand, because the number of children who need assistance is increasing.

\section{- Social Work courses in Estonia}

In Estonia, social work BA and MA programmes allow the training of professional social workers with a specialisation in narrower fields of social work.

\section{Bachelor's:}

(1) Tallinn University, the School of Society and Law (branch of social protection). The BA programme was established in 1991

(2) Tallinn Technical High School, Institute of Service Economy, Practical Higher Education of social work (since 2009), situated in East Estonia (in a small village, Mõdriku). Develops general and specific practical competencies of social workers to promote people's well-being, societal changes and development. In this curriculum there are many courses with low European Credit Transfer System credits that do not support deep treatment of the topic.

(3) The University of Tartu started social work education in 1992, and now they offer a BA course: Info Society and Social Wellbeing (since 2018). It has 25 per cent of courses related to social work, to give kind of broad basis for social sciences. There are two major modules: Sociology \& Info-Science, and Social Work \& Social Policy. This course is not purely a social work programme, but rather a curriculum of general social sciences.

(4) The University of Tartu, Pärnu branch (a college in a small city) offers Social Work and Rehabilitation Work, as a programme of professional higher education (since 2002). It aims to give professional higher education in social sciences focusing on the organisation of social work. It is mostly a practical curriculum (as professional higher education normally is) (Self-Evaluation Report, 2020).

\section{Master's:}

(1) Tallinn University, the School of Society and Law (branch of social protection).

(2) The University of Tartu, Department of Social Work and Social Policy.

$\mathrm{PhD}$ :

Tallinn University, the School of Society and Law (branch of social protection). Doctoral theses of social pedagogy are defended here too. 


\section{References}

Barreiro, A., \& Endsleff, I. K. (2020). A crossroad between personal and collective experience. In M. C. D. P. Lyra, B. Wagoner \& A. Barreiro (Eds.), Imagining the Past, Constructing the Future (pp. 71-88). Cham, Switzerland: Springer.

BNS Survey. (2019). Average Estonian household has six months' worth in savings. Accessed 2 January 2020. https://news.err.ee/1019564/survey-average-estonian-household-has-six-monthsworth-in-savings.

Böhnish, L., \& Schröer, W. (2011). Social pedagogy of the life stages. In J. Kornbeck \& N. Rosendal Jensen (Eds.), Social Pedagogy for the Entire Lifespan (vol. 1, pp. 16-28). Bremen: Europäisher Hochschulverlag.

Broekaert, E., Van Hove, G., D'Oosterlinck, F., \& Bayliss, P. (2004). The search for an integrated paradigm of care models for people with handicaps, disabilities and behavioural disorders at the Department of Orthopedagogy of Ghent University. Education and Training in Developmental Disabilities, 39(3), 206-16.

Eichsteller, G., \& Holthoff, S. (2011). Conceptual foundations of social pedagogy: A transnational perspective from Germany. In C. Cameron \& P. Moss (Eds.), Social pedagogy and working with children and young people (pp. 33-53). London: Jessica Kingsley Publishers.

Eriksson, L., \& Winman, T. (2010). Learning to fly: Social pedagogy in a contemporary society. Boräs: Bording AB. Introduction.

Ewijk, H. (2016). Vajadus uurivate sotsiaaltöötajate järele. In J. P. Wilken \& H. Ewijk (Eds.), Mõtisklusi sotsiaaltööst (pp. 37-9). Tallinn: Tervise Arengu Instituut.

Gustavsson, B. (2010). Knowledge, bildung and action in social pedagogy. In L. Eriksson \& T. Winman (Eds.), Learning to fly: Social pedagogy in a contemporary society (pp. 14-30). Boräs: Bording AB.

Hämäläinen, J., \& Kurki, L. (1997). Sosiaalipedagogiikka. Porvoo: WSOY.

Julge, K. (2016). Health services and well-being of children in Estonia. The Journal of Pediatrics, 177, 63-7. [CrossRef] [PubMed]

Keupp, H. (2002). Identitätskonstuktionen: das Patchwork der Identitäten in der Spätmoderne. Reinbek: Rowohlt.

Kornbeck, J. (2009). 'Important but widely misunderstood': The problem of defining social pedagogy in Europe. In J. Kornbeck \& N. Rosendal Jensen (Eds), The diversity of social pedagogy in Europe (pp. 211-35). Bremen: Europäisher Hochschulverlag.

Leino, M. (2002). 'Sotsiaalsed probleemid koolis ja õpetaja toimetulek'. Doctoral thesis, Tallinn University.

Leino, M. (2010). Sotsiaalpedagoogika ja/või sotsiaalne töö majandusprobleemide kontekstis. Sotsiaaltöö, 2, 38-41.

Leino, M. (2012). 'Problem child' at school - who's problem? The social pedagogical point of view. Saarbrücken: Lambert Academic Publishing.

Mawhood, W. (2015). A very Finno-Ugric feud. The Baltic Times. February 5. Accessed 14 September 2020. https://www.baltictimes.com/a_very_finno-ugric_feud_-_is_the_ukraine_crisis_causing_rifts_ between_estonia_and_a_traditional_ally_/.

Nivala, E., \& Ryynäinen, S. (2019). Sosiaalipedagogiikka. Helsinki: Gaudeamus.

Opikova, G. (2019). 'Depressiivsuse teke Eesti kesk- ja vanemaealistel SHARE uuringu põhjal'. Master's thesis, University of Tartu. Accessed 14 September 2020. http://share-estonia.ee/wp-content/ uploads/2019/10/Magistritoeoe_Galina_Opikova_2019-06-16.pdf.

Payne, M. (2005). Modern social work theory (3rd ed.). Basingstoke: Palgrave Macmillan.

Payne, M., \& Askeland, G. A. (2019). Globalization and international social work: Postmodern change and challenge. London: Ashgate.

Petrie, P. (2011). Interpersonal communication: The medium for social pedagogic practice. In C. Cameron \& P. Moss (Eds.), Social pedagogy and working with children and young people. Where care and education meet (pp. 669-84). London: Jessica Kingsley Publishers.

Rõõm, T., \& Villmann, N. (2002). Estonian labour market in the past decade. Kroon \& Economy, 1, 1-3. https://haldus.eestipank.ee/sites/default/files/publication/en/Archive/kroon_economy/2003/ _023-033Eesti_tooturg.pdf Accessed 25 August 2020.

Schilling, J. (1997). Soziale Arbeit. Entwicklungslinien der Sozialpädagogik/Sozialarbeit. Düsseldorf: Luchterhand.

Schulte, T. (2013). Der Weg zum professionellen Coach. Basel: Beltz Verlag.

Self-evaluation report. (2020). Tallinn University. Estonian Agency of Higher Education. 
Statistics of Estonia. (2019). Accessed 25 August 2020. https://www.stat.ee/news-release-2019159\#: : :text=According\%20to\%20Statistics\%20Estonia\%2C\%2021.7, poverty\%20by\%200.3\% 20percentage\%20points.

Statistics of Estonia. (2020). Accessed 14 September 2020. https://www.err.ee/1127781/eesti-teisekvartali-keskmine-palk-kasvas-uhe-protsendi-1433-eurole.

Sünker, H., \& Braches-Chyrek, R. (2009). Social pedagogy in Germany. In J. Kornbeck \& N. Rosendal Jensen (Eds.), The diversity of social pedagogy in Europe (pp. 12-33). Bremen: Europäisher Hochschulverlag.

Tamm, T. (2010). 'Professional identity and self-concept of Estonian social workers'. Academic dissertation, Tampere University.

Tierney, J., \& Baumeister, R. F. (2021). The power of bad. New York: Penguin.

Webb, S. A. (2006). Social work in a risk society. Basingstoke: Palgrave Macmillan. 